\title{
The determinants of youth labor market integration in Cameroon: is family Socioeconomic-background more effective than education?
}

\author{
Samuel Nouetagni ${ }^{1}$ \& Mathias Kuepie ${ }^{2}$ \\ ${ }^{1}$ University of Yaounde 2 SOA, Researcher at CERASS (Yaounde) \\ ${ }^{2}$ UNFPA, Democratic Republic of Congo country office \\ Email: nouetagni@yahoo.fr
}

\begin{abstract}
Background: The purpose of this study is to measure the impact of socioeconomic background and human capital on young people's labor market integration.

A review of the literature suggests that in addition to human capital, other factors not directly related to individual productivity play an important role in labor market integration.

Data Source \& Method: The empirical work is based on the analysis of a firsthand biographical database from Bafia, a Cameroonian city.

Results: Results show that young people from privileged background are more likely to swiftly enter the wage sector than their peers from disadvantaged background.

Conclusion: This result is not only due to the fact that former received more education than the latter but also because of the existence of a sort of privileged birth-related premium not induced by the formal education level.
\end{abstract}

Keywords: youth; social inequality, education effectiveness; Labor market; family background

JEL classification: J24, J62, J63.

\section{Introduction}

The labor market in Cameroon, as in most subSaharan African countries, is characterized by the scarcity of "decent" jobs, i.e. jobs that can provide more or less adequate and consistent earnings. The Labor Force Survey (20I0) reports that nearly $90 \%$ of jobs are in the informal sector, with insecure business conditions (remuneration level, job security, and social security coverage). Between 2005 and 2010, the total active population of Cameroon grew by $11 \%$, but this growth was mainly supported by the informal sector (12\%), whereas the formal sector increased only by $3 \%$. The few jobs that provide good remuneration and welfare terms, which are found in the modern public and private sectors, are in extremely short supply and hard to access, especially for first-time applicants and particularly when these are young people (Kouamé, Kuepie and Tameko 200I; Brilleau, Roubaud and Torelli 2004; etc.). To survive, the vast majority of young people in Africa are forced to fall back on the informal sector, further contributing to the deterioration of business conditions (cf. Njoya et al, 2008). The few decent jobs on offer are subject to fierce competition, and not all young people enter the labor market with the same strengths, both in terms of human capital and social capital endowments.
According to the classical human capital theory, those with more education should be advantaged in getting better jobs since productivity is positively correlated to human capital. Human capital theory states that investment in the "quality" of the population (education and health) is an important factor for growth and economic prosperity (Becker, 1993; Schultz 1983). At the individual level, those who invest in education improve their productivity and subsequently their income. It has been demonstrated that one additional year of education raises income by $6.5 \%$ on average in Europe and approximately $10 \%$ in the U.S. (De la Fluente and Ciccone, 2002). In African countries, returns to education vary according to the country but are generally important (cf. Psacharopoulos G. \& Patrinos H.A., 2004). Kuepie, Nordman and Roubaud (2009) find increasing marginal returns to education in large African cities, meaning that the gains from education increase more than proportionally with the level of education.

But if human capital and education in particular is undoubtedly an important determinant of labor market integration, it remains that other factors can play an equally important role, especially in the presence of heavy imperfections in the labor market (limited credit, distortion of competition, information asymmetric, etc) as is the case for developing 
countries. Alternative theories have challenged the human capital approach. We can quote the case of the screening theory, which is based on the fact the actual productivity of jobseekers is not known. Employers have to use filters or signals (Spencer, 1998) to rank and select employees that they think will be the most productive. Filters can be based on education or other social characteristics (gender, race, place of residence etc.). Complementary, employers can rely on referrals to find the most suited workers (see Montgomery, 1991). From the jobs seekers perspective, the objective is to have information on available jobs, and to convince the employers to hire them. Those who can resort to a social network will be more advantaged than those who cannot (Munshi, 20l4). An essential component of an individual networks is his close family, especially his parents. In developed countries, measuring the impact of parent economic background on children labor market outcome is a well-covered topic (Peugny, 2007 ). In the developing countries and especially African countries, studies on the subject are still scare, except noticeable works of DoumerPasquier (20I2) and Cogneau and Mesple-Somps (2008). Following these authors, we intend to measure the impact of individuals' socioeconomic background on their position in the labor market of Bafia, a small town in Cameroon. Our paper expands upon earlier studies in two dimensions: first of all, the study field is Bafia in Cameroon, a country where studies on inequalities in labor market are rare. Secondly and more fundamentally, we focus on inequalities in socioeconomic background at a key moment in life, when young people enter the labor market for the first time. Indeed, the first job plays a very important role in future employment status, especially when decent employment opportunities are as rare as they are in African cities. Our study is also innovative in that we use biographical data, which are particularly suitable for the study of young people's labor market integration since they take into account the duration into the unemployed or into a low job status before finding a decent job.

The main result is that young people from privileged background (measured by the father employment status and the living standards in the household of the origin) are more likely to swiftly enter the wage sector than their peers from disadvantaged background. This result is not only due to the fact that youth from privileged background received more education but also because of the existence of a sort of privileged birth-related premium not induced by the formal education level.

\section{Literature review}

The idea that family background is a determinant of the socio-professional status is an old idea (Durkeim, 1895; Marx, 1867, etc.). Bourdieu (1980, 1984) among others, popularized this idea in France. $\mathrm{He}$ argued that individuals use not only their own talents and personal resources to achieve their goals, but also the resources of their families, communities and other organizations to which they belong. Looking specifically at labor market integration, Pasquier-Doumer (20/2) suggests that socioeconomic background, measured in her study by parental occupation, influences children's labor market integration through three channels: the possibility to mobilize family material resources, the transmission of specific know-how or specific human capital developed within the household, and the possibility to mobilize the social network to access the best opportunities. In this study, we focus on employment in the wage job sector wherein mobilizing the family of origin's social capital may be particularly significant. This therefore calls for a more detailed definition of this concept. Bourdieu states that social capital is a form of acquired collective resource that the individual receives from his or her group or social network. Capital is also built through social activities such as associations, friendship or partnership, religious movements, political mobilization and sports clubs. It could therefore be seen as a product of the social structure (Coleman, 1988) or as a result of the action of the individual who built it through his participation in associations (Putnam, 2000).

In his theory of "structural holes", Burt (1995) defines the concept of social capital on the basis of the absence of social relations. Here, social capital is created when, in the absence of relationships between actors " $A$ " and " $B$ ", " $A$ " bridges the gap through an intermediary to contact " $B$ ". Burt calls the lack of relationship between two actors a structural hole. The particular value of bridging the structural holes is that it helps individuals reaching beyond their own immediate social network to surrounding social networks. In other words, the creation of new contacts beyond the immediate social circle extends the social network of information and therefore enhances social capital. In a climate of scarce decent jobs as in Cameroon, young people who can bridge the structural holes to meet employers have an advantage in the job-seeking process once they have ended school.

Empirical studies show that personal and professional contacts are still the most frequent method used to seek and secure a job. Even in a country with a structured labor market like France, the main way for executives to find a job is through 
their personal contacts (APEC, 2006). This study shows that about $29 \%$ of jobseekers specifically use their private network to find a job (Poullaouec T., 2003); the percentage is similar in Algeria (Fraihat HS, 2003). In sub-Saharan Africa, private channels are more active in helping people getting jobs. For example, in the case of the WAEMU labor market, Brilleau, Roubaud and Torelli (2004) show that the majority (two-thirds) of people looking for a job rely mainly on their personal and family relationships. In a study of the strategies used by young people to find work in the city of Yaoundé, Mambou P. F (2008) finds that friendships and family relationships are the most used job-seeking channel (almost half of the employed young people reported using that channel), at the expense of public employment agencies such as the National Employment Fund (FNE).

Hence, far from being official employment agencies, the job-seeking channels used are individual contacts. In this situation, young people from underprivileged background are at more of a disadvantage than those from privileged background because the latter can rely on a more effective social network comprising individuals at the top of occupational hierarchy (Silberman and Fournier, 1999). Advantaged young people have more access to information on the best jobs available in the labor market, compared to those from working class background. Yet beyond the lack of access to information for young working class people due to the inefficiency of the networks to which they are connected, there is also the issue of informal household human capital production. Indeed, socioeconomic background can also act through informal skill production in the household. Heckman (20I2), strongly advocates early intervention to provide a positive learning environment for the child. Thus, he identifies character skills that he says are crucial in early years, including openness (curiosity, willing to learn); Conscientiousness (staying on task); extroversion (outgoing, friendly); agreeableness (helpful); neuroticism (attention to detail, persistence). All these behavioral elements are more susceptible to be developed within households with higher socioeconomic status, because parents with high social status have more means and know-how to develop these skills. The informal human capital has been proven to yield high return in the labor market (Heckman, 20l2; Gertler et al, 20l3). Gertler et al(20l3) findings on the effects on earnings of a randomized intervention that gave stimulation to stunted toddlers living in poverty, show that simple socio-emotional stimulation in earlier childhood in disadvantaged settings can have a substantial effect on labor market outcomes and reduce inequality later in life. Gertler's et al paper clearly shows that parents are children's first and most important teachers. The more able are these "first teachers", the more their children will have an advantage on other when integrating the labor market.

Finally, socioeconomic origin can act on children labor market integration through two complementary mechanisms: a networking mechanism and a household informal human capital production mechanism. In this study, we cannot disentangle the two components since they are jointly determined by the social origin.

One way of measuring the importance of social origin in the level of employability is to analyze the relationship between the positions of fathers and children in the labor market. C. Thélot (1982) was among the first in France to rigorously examine this relationship. He shows that, contrary to the prevailing discourse on meritocracy and social mobility during the post-war economic boom period, children from disadvantaged background more often held jobs at the bottom of the socioeconomic ladder, compared to those from more advantaged background. In other words, the place of the son in the labor market is determined by that of the father. While much of this can be explained by the difference in human capital between working class children and upper class children, the latter still have better professional positions than the former even when they have the same level of education. Thus, even when upper class French children do less well in their education, for one reason or another, they can receive parental support to limit the effects of this lag. The author calls this overprotection a "ratchet effect". Twenty five years after Thélot's study, Peugny C. (2007) shows that even though education is now widely available to all in France, the socioeconomic background of individuals born after 1960 continue to play an important role in their social mobility, a sign that the "ratchet effect" found by Thélot is still at work. Lastly, the author talks about "destiny in the cradle" (Peugny, 20/3) to describe the fact that in France 7 out of 10 children of parents with executive jobs are in managerial positions, while 7 out of 10 children of working class parents are subordinate employees.

Economists have only very recently turned their attention to analyzing the relationship between socioeconomic background and the position of individuals in the labor market in Africa. Among these recent studies, Cogneau and Mesple-Somps (2008) look to Côte d'lvoire, Ghana, Guinea, Madagascar and Uganda to compare the "inequality of opportunity" between countries based on household surveys (LSMS-type). The authors show that social mobility opportunities depend less on the parents' employment status in the former British colonies 
(Ghana and Uganda), while the son's labor market position and earnings are highly dependent on the father's in the former French colonies (Côte d'lvoire, Guinea and Madagascar). This study therefore highlights how different public policy environments (inherited from France on the one hand and from Great Britain on the other) can shape the inequality of opportunities. Yet the data used by these authors do not provide a detailed measurement of the parents' occupational categories, especially in the context of the labor market where the nonagricultural informal sector plays as important a role as it does in the African countries. Pasquier-Doumer (20I2) addresses this problem using data from surveys conducted in seven job capitals in West Africa . An important conclusion she draws is that, while labor market inequalities due to socioeconomic background are transmitted mainly through inequalities in access to education in the coastal cities (Lomé, Cotonou, Dakar and Abidjan, to some extent), these inequalities result from both differences in access to education and a pure family background effect in landlocked and less developed cities (Niamey, Ouagadougou and Bamako). The way labor market inequalities are transmitted in these last three cities is similar to that found for France by Thélot (1982) and Peugny (2007).

\section{Data and variables and methods Data}

The data come from a 2010 biographical survey in Bafia a small town in Cameroon on poverty and the unmet need for the reproductive health of young people and adolescents in Bafia. This survey's goal was to highlight the interactions between poverty and the reproductive health of young people (aged 15-34). The sample units (the young people) were randomly selected using the following multistage sample design: at the first stage twenty-one out of 42 enumerations areas were drawn with probability proportionally to size. Within each enumeration area, a census of all household was conducted, with an enumeration of all young people aged 15-34 living in households. 5340 households and 2783 young people were identified. In a second stage 1859 young people have been sampled following a simple random sample design, and 1579 actually interviewed. Although its main purpose was not to study intergenerational occupational mobility, the information collected nevertheless enables this issue to be addressed. The biographical questionnaire contains four modules. The first is the "migration and housing history" module, in which respondents' living conditions and the employment status of parents in different households are recorded. Another useful module for this study is the "employment history" module, in which the different education and activity periods are registered. The last two modules - "sex life and partnerships" and "fertility" - are not relevant to this study. The total sample contains I,577 interviewed young people and adolescents. For our analysis, we consider only the young people (about 930) who have completed their education cursus.

Unlike cross-sectional data, biographical data record the temporal sequence of events and therefore allow for a study of the causal relationships between events (Bocquier 1996; Courgeau and Le Lièvre, 1989). Another important advantage of biographical data over conventional data is that they reflect the heterogeneity relating to the time before the occurrence of a given state. For example, in our case, we are interested in the impact of family background and education on access to employment. With cross-sectional data, we would only have information on the activity status of each person at the time of the survey: wage earner, self-employed or unoccupied. With biographical data, we can take into account the time between leaving the education system and current employment status. This provides information on how long wage earners, selfemployed and unoccupied individuals have been in this situation. Also, family background characteristics are measured at the time they were leaving the education system, before labor market entry. We explain below how the different variables are built.

The main dependent variable: time period before entering a wage job.

The labor market module contains variables that trace young people's career paths. From leaving the education system through to the survey date in 2010 , we can identify:

- Periods of education

- Periods of inactivity and unemployment

- Periods of activity.

Suitable questions are asked about each particular period in order to identify its characteristics. Education level and graduation are recorded for the periods of education, while the questions asked for the periods of activity identify the nature of the work: wage job, self-employed, employer or family worker. These questions serve to build our dependent variable, which is the time period lasting from leaving the education system to entering the wage job sector.

\section{Measurement of human capital and social origin} Measuring human capital is not an easy stuff. Usually, it is approximated through the education level achieved by an individual. But, two persons with the same level of education can have very different cognitive abilities, both because of the heterogeneity 
in training system, innate ability, and the family background. The latter source of heterogeneity is control for the type of education received, but at least, we can disentangle technical education from general education. In our Database, we also have information on the highest diploma achieved by individuals. It is important to stress that diploma examinations are organized at the national level and not at the school level, so that two persons with the same diploma may be more similar (in terms of competence) than two persons with the same number of successfully years of education. Combining the type education (technical versus general) and the certification (succeeding in the diploma examination) enable us, to a certain extent, to take into consideration the complexity of measuring human capital. Concretely, the following categories are considered: primary without diploma; primary with controlled in our model. As the training system is concerned, our data do not allow us to precisely diploma; lower secondary without diploma; lower secondary with diploma; upper secondary and high education without diploma; upper secondary and high education with diploma. In an alternative specification, we consider technical education diploma versus general education diploma.

Overall,: $17 \%$ attended primary school without obtaining any diploma, $16 \%$ completed the primary school with a diploma, $35 \%$ attended the lower secondary school but didn't succeeded the diploma, while only $9 \%$ obtained the diploma. Concerning the upper secondary and higher education, about $17 \%$ of young people of Bafia attained this level but without diploma, against $6 \%$ who attained the level and graduated.

Table I. Distribution of education level and diploma in Bafia , Young people aged I5-32 who have left school.

\begin{tabular}{|l|r|r|l|r|r|}
\hline eEducation level & N & $\%$ & diploma & N & $\%$ \\
\hline primary without diploma & 160 & 17,22 & none & 443 & 47,69 \\
\hline primary with diploma $\left.*^{*}\right)$ & 151 & 16,25 & CEPE & 255 & 27,45 \\
\hline lower secondary without diploma & 329 & 35,41 & BEPC & 88 & 9,47 \\
\hline lower secondary with diploma $\left.*^{*}\right)$ & 82 & 8,83 & CAP (Technical diploma) & 89 & 9,58 \\
\hline upper secondary and high education without diploma & 154 & 16,58 & baccalaureate or more & 54 & 5,81 \\
\hline upper secondary and high education with diploma $\left.*^{*}\right)$ & 53 & 5,71 & Total & 929 & 100 \\
\hline Total & 929 & 100 & &
\end{tabular}

$\left(^{*}\right)$ the diploma taken into consideration are: primary certificate for primary, "BEPC or CAP" for lower secondary, and "Baccalaureate or university degree" for upper secondary and university

Table I also provides the distribution of young people according to the type of diploma obtained. The main information which comes from this distribution is that about $10 \%$ of young people hold a technical diploma and only $6 \%$ have the baccalaureate or other higher diploma. We will see later how effective is the technical diploma "CAP" (which requires the same years of school as the lower secondary diploma "BEPC" ) in integrating labor market, compared to the general education diplomas "BEPC" and Baccalaureate.

The measurement of socioeconomic also background is relatively complex. In this study, we use two indicators: the father's employment status and the family's standard of living. With respect to the father's employment status, $35 \%$ of young people had a father working in the wage sector at the end of their education period, the same proportion had retired or unemployed fathers, and about $30 \%$ had a self-employed father.

To build the living standards indicator, we combine information on housing characteristics and household commodities ownership. This information is measured for when the young people leave the education system and before they enter the labor market. The multiple correspondence factor analysis (MCA) method is used to build the living standards index. Filmer and Pritchett (200I) show that the application of this method to household commodities and housing characteristics generates an appropriate indicator of "permanent living conditions" in developing countries. The advantage of the MCA (and factorial methods in general) compared to a simple sum of items (weighted or not) is that it can assign weights to individuals and variables depending on their contribution to explaining total inertia (Asselin, 2002).

The descriptive statistics for the variables used in this analysis are presented in table $\mathrm{Al}$ in the appendix. It is important to mention that answers about assets are susceptible to recall errors because they refer to household living condition when the interviewees were still at school, so longtime ago for some of them. But these recall errors should be attenuated because assets are durables goods which were daily used and hence interviewees should 
normally know if theses goods were or not in the household. Table IA in appendix shows that the Once we had conducted the MCA, we recovered the factorial weight of individuals on the first factor. The latter explains alone about $80 \%$ of total inertia, that is the total variance of the data. The second only explains $5 \%$ and the third just 3\%. In other words, the first factorial axis pretty well sums up the information contained in the variables. The extra dimensions reflect almost white noise.

The factor score for individuals on the first axis can be used as an indicator of socioeconomic class. Since the metric of this factor does not itself have an immediate socioeconomic meaning, we transform the first factor into quintiles. Preliminary analyses show that individuals in the first two most privileged quintiles are clearly detached from the three poorest quintiles. We split the first factor in two separate socioeconomic classes: the $60 \%$ less advantaged and the $40 \%$ most advantaged classes.

\section{Analytic methods}

This study uses essentially duration analysis methods. At the descriptive level, we use the Kaplan-Meier method. At the multivariate level, we use the Cox regression. Both methods have in common the fact that the dependent variable is the time period before the event of interest and not the event itself. Two individuals may both have exactly the same employment status at the survey date (both wage earners, for example) and the same characteristics (level of education, socioeconomic background, etc.), but have different contributions to the likelihood function if the time taken to reach this status is different between the two individuals. For more information on Kaplan-Meier and Cox methods, readers may refer to Courgeau and Le Lièvre (1989) or Cox and Oakes (1984). frequency of the category "Unknown" is very low (generally less than 1\%)

The issue of unobserved ability.

The family background (father's working status, household living conditions) and the child's labor market integration process may be both driven by a common family unobserved ability. In that case, our estimations may be biased. But it is reasonable to suppose that children from disadvantaged background who, despite this initial unfavorable conditions, performed well in school also have a high unobserved ability (even higher than that of well-born children with the same level of education). So if labor market better performance was essentially driven by unobserved ability, we should at least observe, for the subset of children with higher level of education, that those from disadvantaged background have at least the same labor market performance (since their high level of education is mainly due to their high ability) as those with from privileged background. But results presented in sub-section 4.4.3 show that even within the sub-group of those with high level of education, children from disadvantaged background still perform less than wellborn ones (cf. Figure 7).

\section{Results \\ General description of the sample}

Table 2 below shows that a total of 929 young people are included in the analysis. This is the set of individual subjects "exposed" to getting a wage job. The total number of months of exposure is $86,5 \mathrm{I} 3$, with an average exposure time of 93 months, which is equivalent to about eight years. The median is about 7 years ( 83 months). Of the 929 young people exposed on leaving the education system, only 175 will actually get a wage job during the period of observation. The total access rate is a little less than a quarter (19\%). All these parameters suggest that access to a wage job is extremely rationed in Bafia, as in all African cities.

Table 2. Description of the sample of individuals exposed to getting a wage job in Bafia

\begin{tabular}{|l|r|r|r|r|r|}
\hline Parameter & \multicolumn{1}{|c|}{ Total } & Mean & Minimum & Median & Maximum \\
\hline Individuals exposed & 929 & & & & \\
\hline Exposure time & 8613 & 93.12 & 1 & 83 & $28 \mathrm{I}$ \\
\hline $\begin{array}{l}\text { Number of young people who } \\
\text { obtain a wage job during the } \\
\text { observation period }\end{array}$ & 175 & 0.19 & 0 & 0 & 1 \\
\hline
\end{tabular}

Before focusing on more complex analyses, it is important to give a general picture of Bafia youth labor market parameter, precisely the participation rate and sector of activity. 


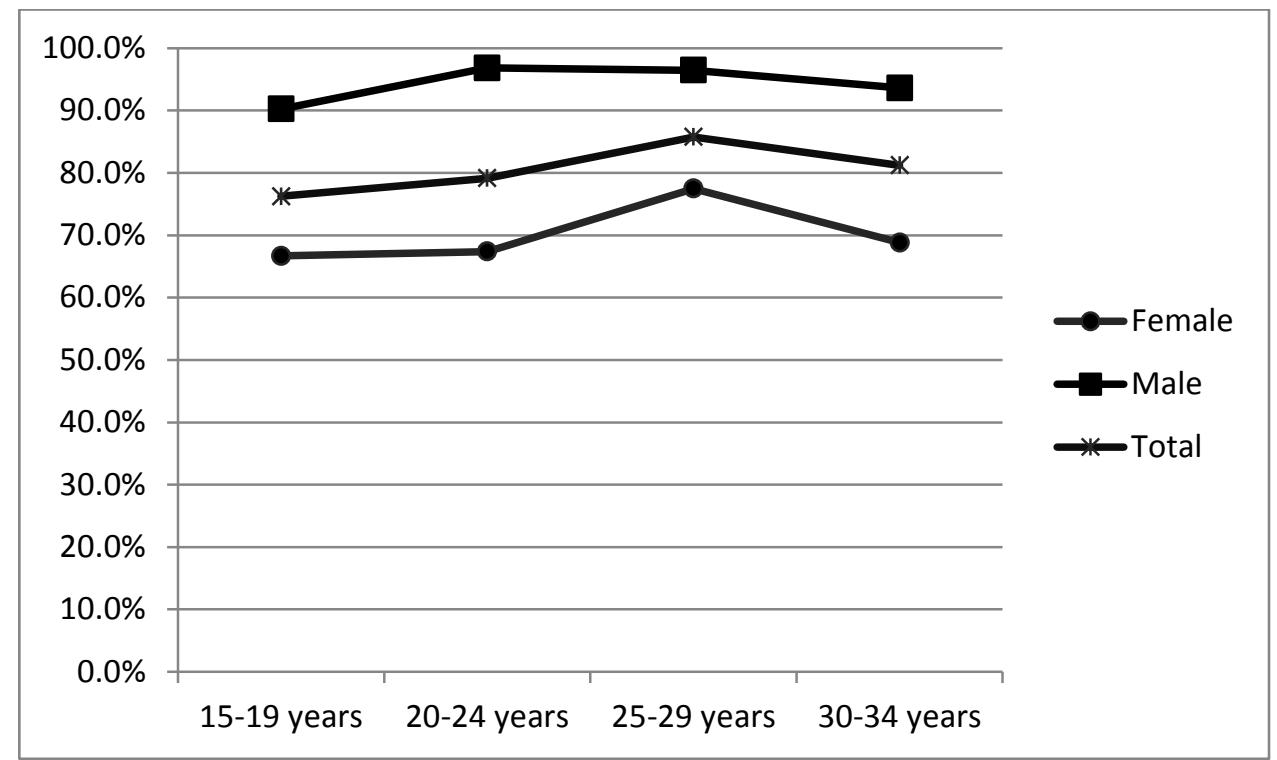

Figure I. Participation rate young people who have left school in Bafia.

Figure I shows that the participation rate is higher for boys (more than 90\%) than girls (Around 70\%). When boys leave the education system, almost all of them are available to work in the labor market. On contrary, a significant proportion of girls do not enter the labor market at the end schooling period. They are oriented toward family live and household activities.

For those with an employment, the huge majority $(80 \%)$ is self employed in the informal sector, and only $20 \%$ earn a wage (cf. figure 2). As we said in the introduction, this is a commons feature of labor markets in developing countries, especially in Africa countries. Bafia is not an exception to this rule. We also notice that boys are slightly more present in the wage sector than girls ( $22 \%$ against $16 \%$ ). But it is important to stress on the fact that some girls may prefer focus on their family live and household activity rather than working in the informal sector.

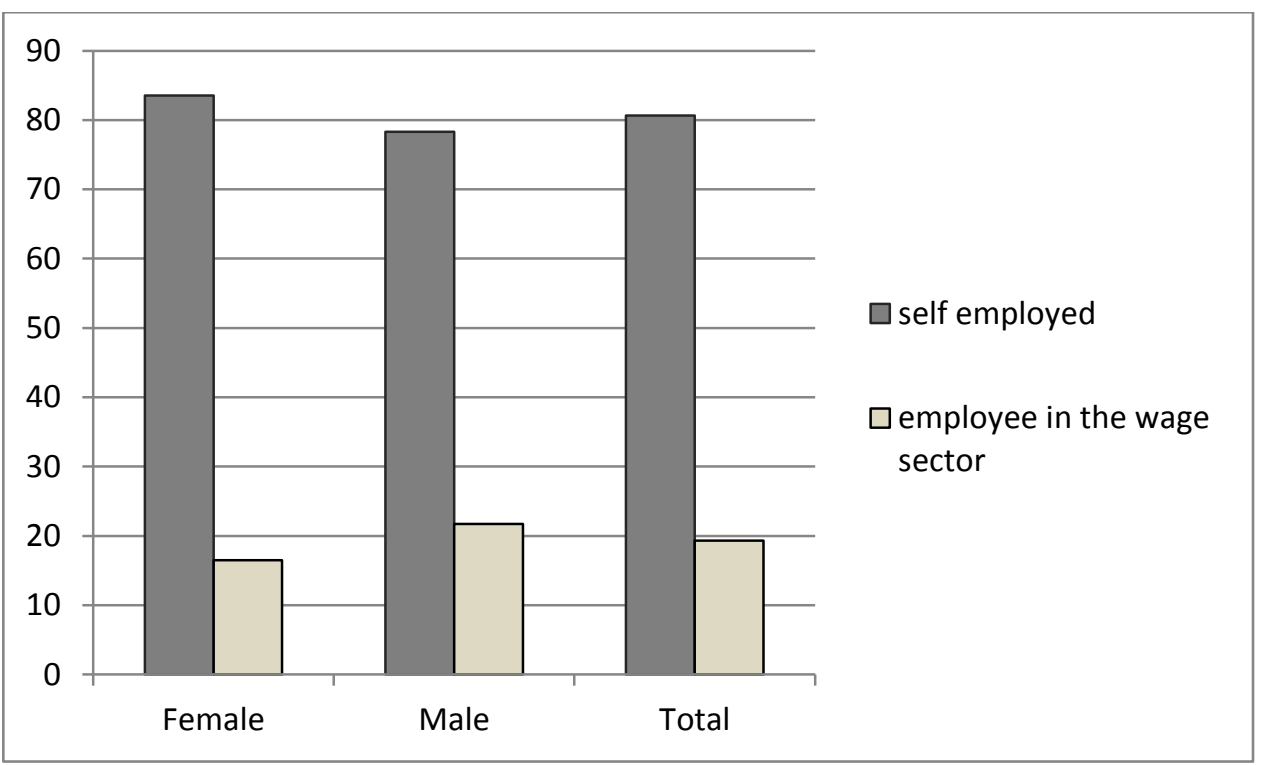

Figure 2. Sector allocation of young people with an employment in Bafia

After the presentation of these general figures of youth employment in Bafia, we now turn to the analysis of the impacts of education level and family background on accessing the tiny but decent wage sector of the labor market.
Influence of education on access to a wage job The influence of the level of education on labor market integration has long been established and demonstrated: being educated gives access to the best niches in the labor market (Kuepie and Nordman, 20II, Doumbia and Kuepie, 2008, etc.). Our analyses confirm this well-established result in the literature: the more educated young people are, 
the more likely they are to quickly find employment in the wage sector. Yet our data reveal some specific findings in addition to this general observation. Firstly, there is an important gap between young people who reached the upper secondary education and others (cf. figure 3): below the upper secondary education, the chances of accessing paid jobs are very low and saturate very quickly: young people whose level of education is lower secondary or less and who do not find a wage job within the first year have virtually no chance of finding later one. Secondly, up to the upper secondary and high education, the certification of the education level by a diploma doesn't seem to improve access to job paid job. For those who reached the upper secondary education, certification is very important, since it almost doubles the chance of getting a paid job.

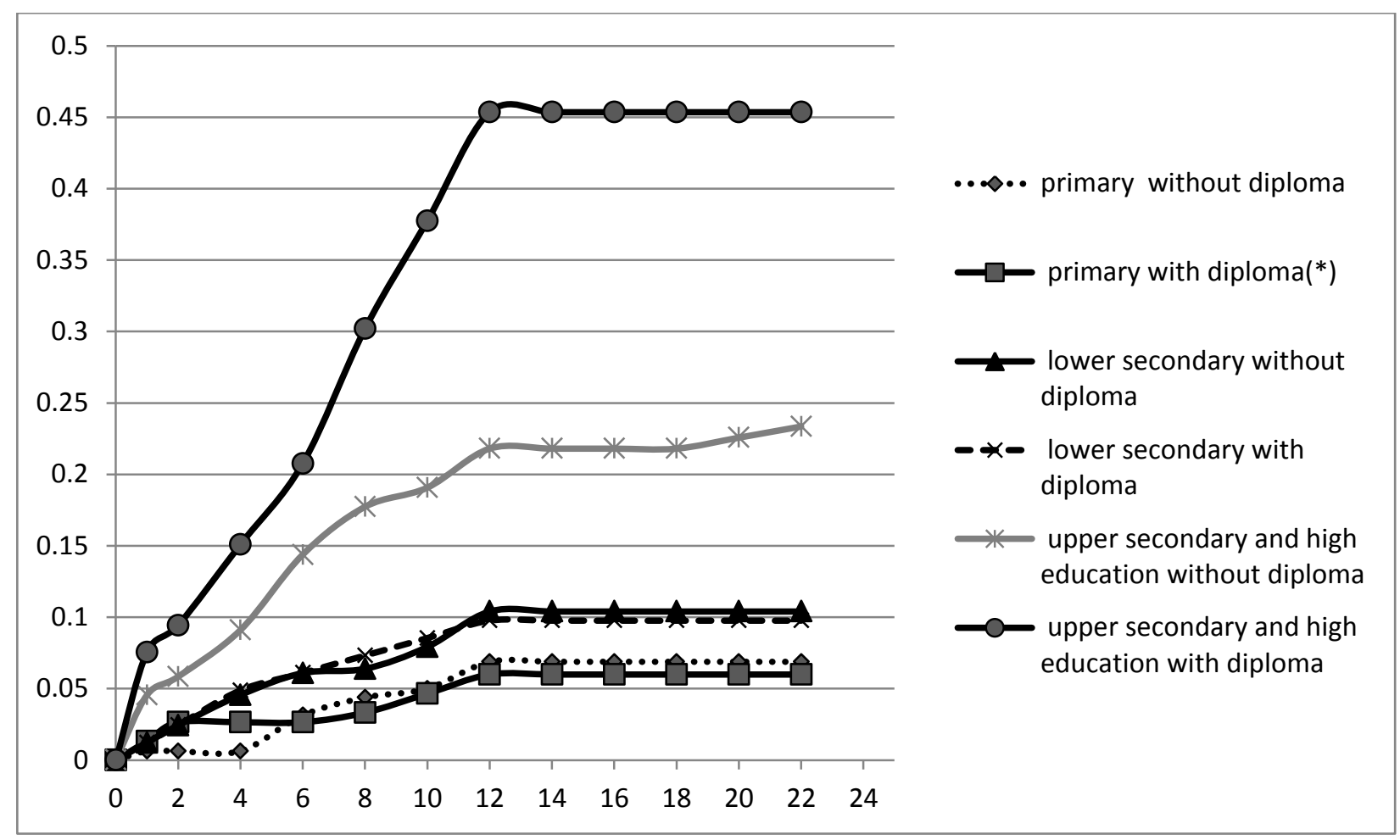

Figure 3: Proportion of young people who find a wage job after leaving the education system by education level

We now look at the link between the Technical certificate "CAP" (which requires the same number of years of education as the lower secondary education Certificate). Figure 4 shows that young people with a Technical certificate are three times more numerous to integrate paid job sector than those holding a lower secondary education Certificate. It is also worth noticing that they integrate paid job sector very quickly. Up to five months, they even move into that sector at the same speed as those holding a baccalaureate, although the latter have four years of education than the former. 


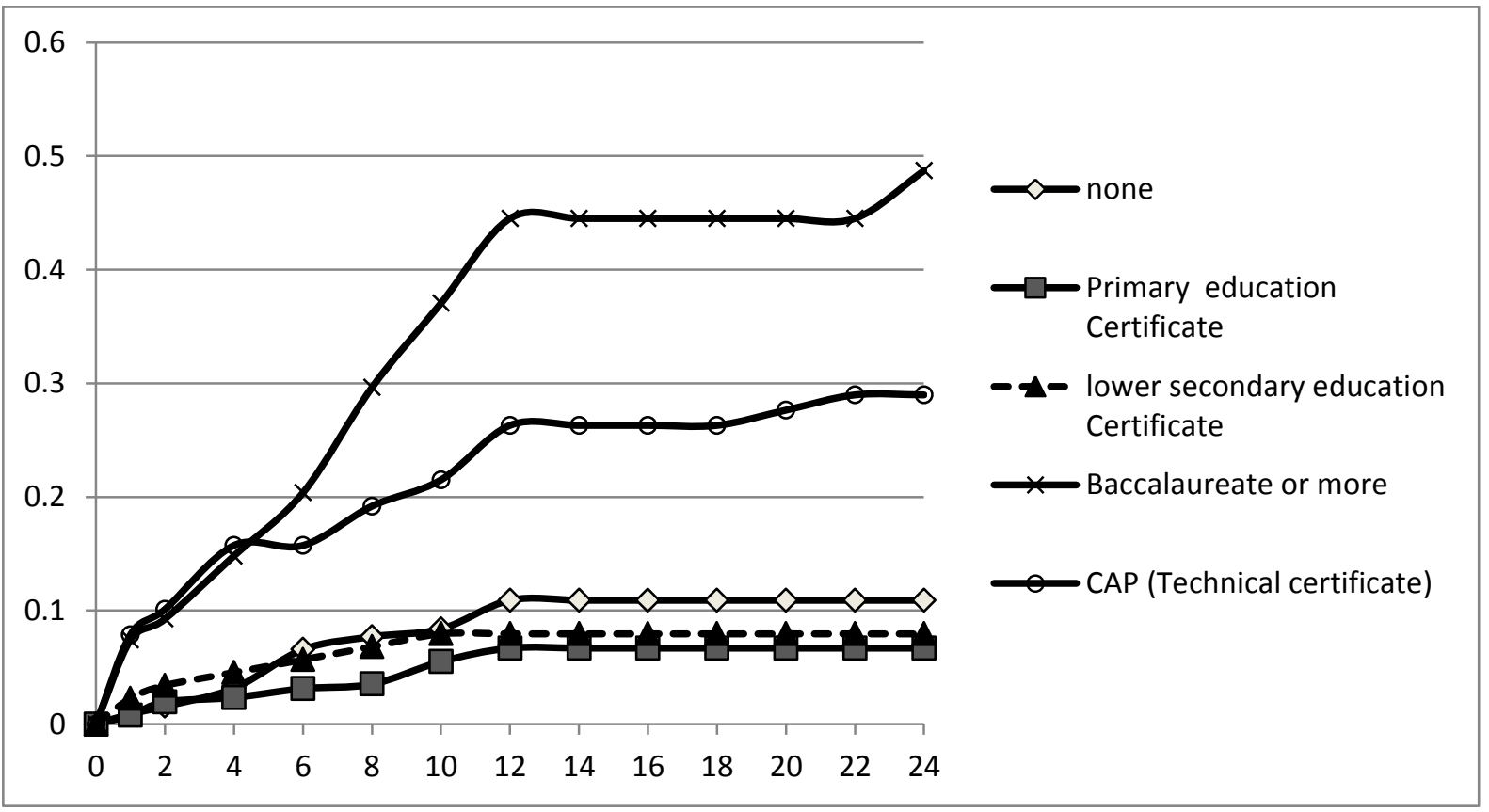

Figure 4: Proportion of young people who find a wage job after leaving the education system by type of diploma

Influence of family background on access to a wage job

As noted above, the family background is measured by two indicators: firstly the employment status of the father and secondly, the wealth index of the household of the family of origin. This index is built from an ACM on the living conditions of the household. Both indicators influence access to employment.

Regarding the wealth indicator, Figure 5 shows that young people from poor households find it harder than others to find a first job in the wage sector. Just under $10 \%$ find wage job within a year of starting their job search as opposed to $17 \%$ of young people from privileged classes. Five years after graduation, there are still large differences between the two classes since only $12 \%$ of young people from poor households are wage earners while this proportion rises to $22 \%$ among young people from more affluent households.

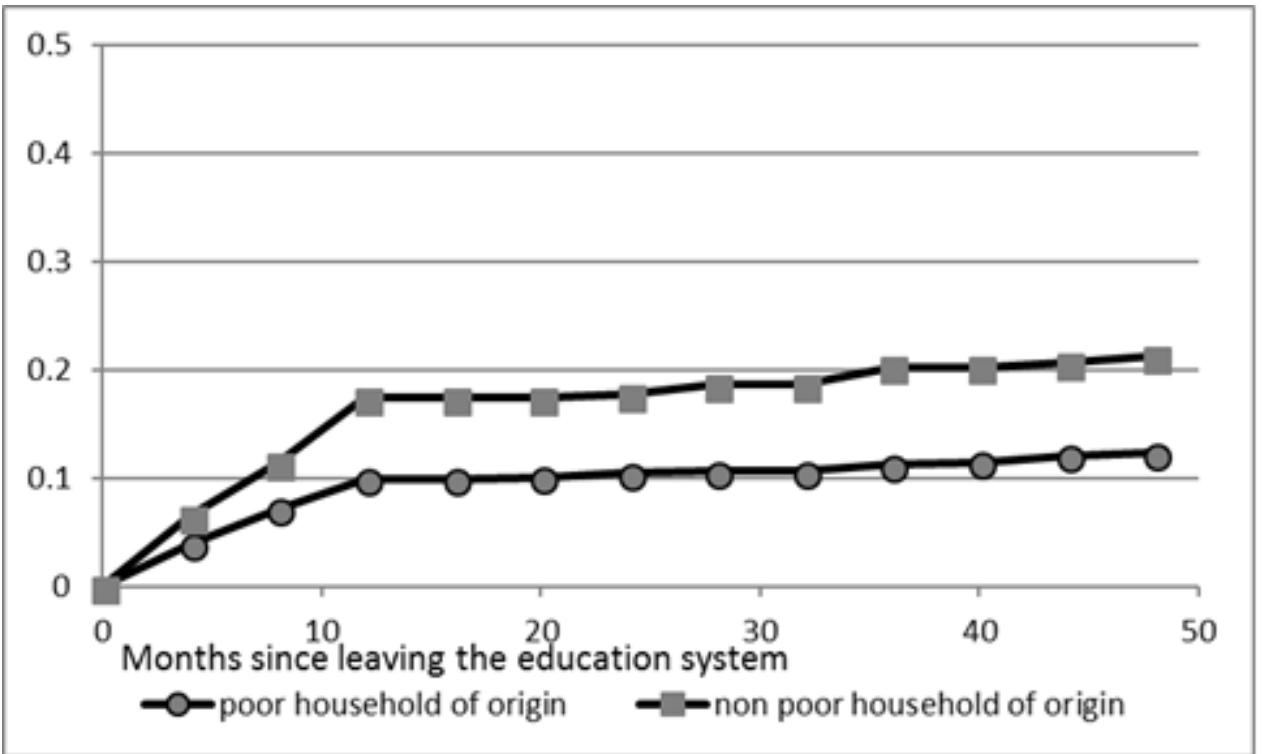

Figure 5: Proportion of young people who find a wage job after leaving the education system by the household of origin's wealth status

With respect to the employment status of the father, Figure 6 shows that individuals with wage-earner inactive. Yet it is important to note that these differences diminish over time. Indeed, while nearly fathers gain faster access to the wage sector than those whose fathers were either self-employed or $17 \%$ of wage earners' children find work as wage earners themselves within the first year of being in 
the labor market, against only $10 \%$ in the other two categories, after five years, $20 \%$ of wage earners' children are employed against nearly 15\% of the children of self-employed individuals. Another striking result is the fact that the children of inactive fathers do not do so badly in the labor market. This may be due to the fact that they form a heterogeneous category covering both children of currently unemployed individuals and children of retired individuals, who may be better off.

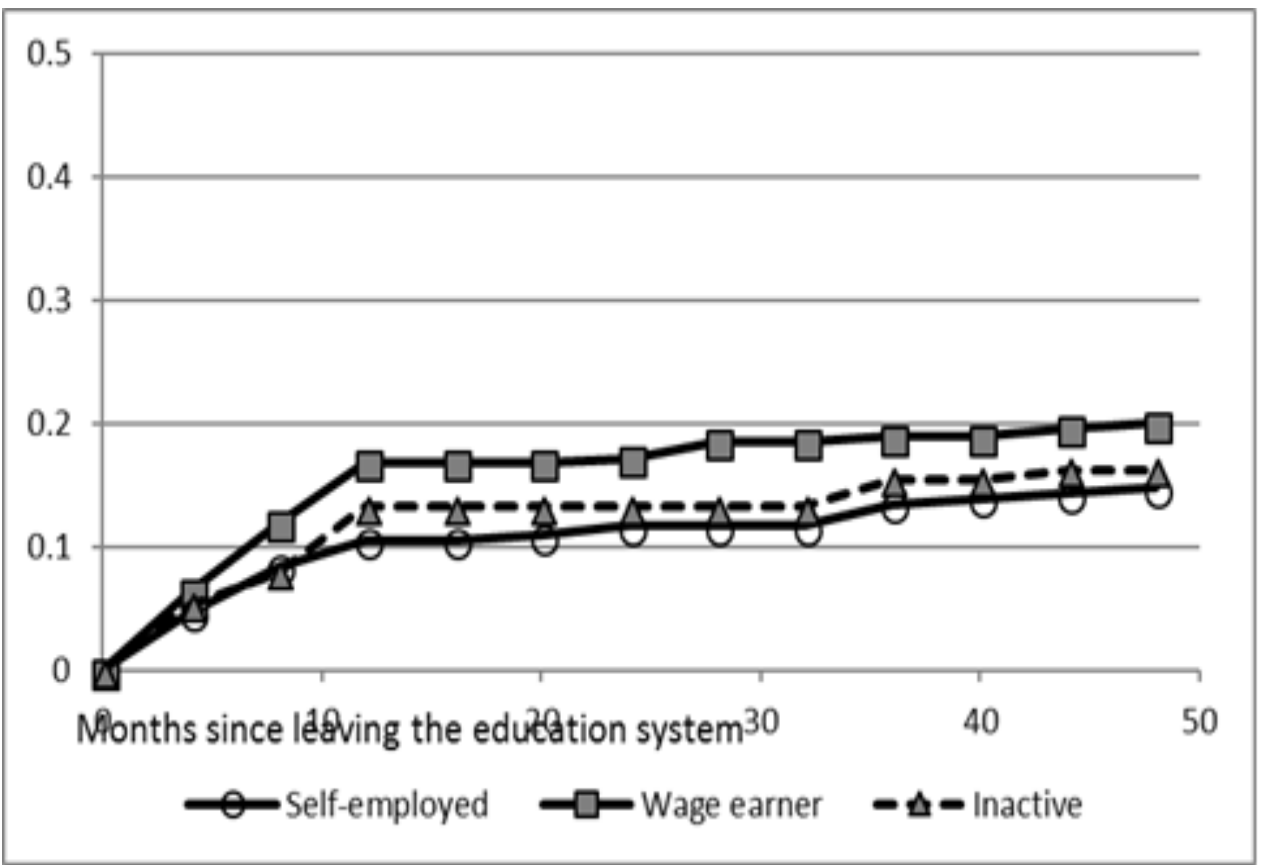

Figure 6: Proportion of young people who find a wage job after leaving the education system by father's employment status

Lastly, although the descriptive results presented above do not make for a clear-cut conclusion as to the reality of the specific effects of human capital variables and social origin on labor market integration, they do reveal the existence of significant inequalities among young people. The following explanatory analyses disentangle the net effects of family background from those due to education itself.

\section{Explanatory analysis}

Previously, it was found that young people with an advantage in terms of family background or education level were more likely to quickly access wage jobs than those at a disadvantage from these two points of view. In this section, we complete the analyses by controlling simultaneously for all the variables. We also pay special attention to the interaction effect between human capital and family background. Lastly, although not a central issue of our study, we take a quick look at gender differences.

\section{Impact of the two main explanatory factors}

We build series of Cox models (Table 3 ) all with the same control variables (gender, region of origin, religion and age), but differing in their main explanatory variables. In the first model (column I), we measure the effect of education level, without controlling for family background. The second and http://aps.journals.ac.za third columns present two models measuring the effect of each of the family background factors (father's employment status and household wealth), excluding education level. The fourth (column 4) integrates these two family variables simultaneously, while the fifth model (column 5) includes education level in addition to the above variables and the last includes the diploma in the place of education level.

The first result that emerges from this table is the validation of almost all the descriptive results presented above: each key explanatory factor has its own intrinsic effect, although this effect decreases more or less when simultaneously controlling for other factors in models 4 and 5 . Thus, with regard to the father's employment status, there is a certain reproduction of wage earner status because the fact that the father was a wage earner significantly increases the young people's chances of quickly entering the wage sector on leaving the education system. The other family background variable, namely the living conditions is no more statistically significant once education is controlled. This means that effect observed in descriptive analysis is an indirect effect, which passes through education. In other words, if children from households with better living perform better in labor market, it is because their parents invested more on their education. On 
the other hand, the fact that the impact of father's employment status persists even after controlling for education means that if young people whose fathers were not well integrated in the labor market find it hard to find decent jobs, it not only due to the fact that they have a low level of education on average, but also because of a lack of access to information networks and recommendations. These results are similar to those observed in the French context (Peugny, 2007) and in West African landlocked cities (Bamako, Ouagadougou, Niamey), but differ from those obtained in other coastal cities such as Lomé, Cotonou, Dakar and Abidjan, where family background, once education is controlled for, do not anymore influences labor market outcomes (Doumer-Pasquier, 20/2). In the conclusion, we discuss the implications and connotations of this persistent family background effect on access to wage sector jobs.

Even when controlling for other explanatory factors, human capital is the most important determinant in getting a wage job, especially for young people who have completed upper secondary school or above. Indeed, the results in Column 5 of Table 3 show that they are 3.4 times more likely to quickly find a job in the wage sector, compared to young people who left the education system at lower secondary or primary level. This result means that, despite the social background effect, academic success remains an important determinant for good labor market integration. Although the human capital effect is measured here in terms of access to employment rather than earnings, as is the case in most studies on the subject, the results can also be interpreted in terms of performance or efficiency of education. As such, our results are similar to those found by Kuepie Nordman and Roubaud (2009) and Kuepie and Nordman (20l I). We also notice that contrary to descriptive analyses, those who didn't reach the upper secondary education do not improve their chances of accessing the wage job sector, once controlled for the family background. This result seems to mean that at lower levels, the education effect entirely passes through the family background. We will go through this idea later, by crossing family background and education level. It's also worth noticing that Technical Certificate, even after controlling for family background, remains a determinant of labor market integration (column 6) meaning that vocational training is more effective than lower secondary education. The higher effectiveness of vocational training over general education has also been highlighted in other studies (Bennell and Segerstrom, 1998; Middleton et al. 1993; Arriagada \& Ziderman, 1992, Moenjak \& Worswick, 2003)

Table 3. Impact of social origin and education level on the time taken to access wage employment in Bafia (Cox model).

\begin{tabular}{|c|c|c|c|c|c|c|}
\hline VARIABLES & $\begin{array}{c}\text { (I) } \\
\text { Education } \\
\text { level+Contr } \\
\text { ols }\end{array}$ & \begin{tabular}{|c|}
$(2)$ \\
Household \\
wealth \\
status \\
+ Controls
\end{tabular} & $\begin{array}{c}(3) \\
\text { Father's } \\
\text { employment } \\
\text { status + Contr } \\
\text { ols }\end{array}$ & \begin{tabular}{|c}
$(4)$ \\
Father's \\
employmen \\
t status+ \\
Household \\
wealth \\
status + Co \\
ntrols
\end{tabular} & $\begin{array}{c}(5) \\
\text { Education } \\
\text { level+ } \\
\text { Household } \\
\text { wealth status } \\
\text { + Father's } \\
\text { employment } \\
\text { status + contr } \\
\text { ols }\end{array}$ & $\begin{array}{c}(6) \\
\text { Diploma+ } \\
\text { Household } \\
\text { wealth } \\
\text { status + } \\
\text { Father's } \\
\text { employme } \\
\text { nt } \\
\text { status +co } \\
\text { ntrols }\end{array}$ \\
\hline $\begin{array}{l}\text { Education level (primary=reference) } \\
\text { primary with diploma }\left({ }^{*}\right) \\
\text { lower secondary without diploma } \\
\text { lower secondary with diploma } \\
\text { upper secondary and high education } \\
\text { without diploma } \\
\text { upper secondary and high education } \\
\text { with diploma } \\
\text { Diploma (ref=None) } \\
\text { Primary Certificat }\end{array}$ & $\begin{array}{c}1.012 \\
(0.339) \\
1.163 \\
(0.353) \\
1.270 \\
(0.477) \\
1.982 * \\
\\
(0.692) \\
4.195 * * * \\
(1.665)\end{array}$ & & & & $\begin{array}{c}0.950 \\
(0.319) \\
1.066 \\
(0.326) \\
1.083 \\
(0.414) \\
1.697 \\
\\
(0.606) \\
3.279 * * * \\
\\
(1.353)\end{array}$ & 0.844 \\
\hline
\end{tabular}


BEPC (lower secondary education

Certificat)

Technical diploma (CAP)

Baccalaureate or more

Wealthier households

Father's employment status

(inactivity $=$ ref)

Wage earner

Self-employed

Male $(\mathrm{ref}=$ female $)$

Born in the Bafia Region

Religion (ref $=$ Catholic)

Protestant

Muslim

Other Christians

No religion

Age

Exposure time (in months)

Pseudo-R ${ }^{2}$

$S E$ in parenthese

*** $\mathrm{p}<0.01$, ** $\mathrm{p}<0.05$, * $\mathrm{p}<0.1$

Impact of other control variables : significant gender differences.

Differences between girls and boys are very important. In fact, in each specification, boys are at least 2.3 times more likely than girls to find a wage job quickly. It is important to stress the fact that this result is obtained after controlling for human capital and other disturbance variables. This finding is in keeping with numerous studies on the subject of inequality between men and women in the labor market (see Normand, Rakotomanana and Robilliard, 2009, Doumbia and Kuepie, 2008, etc.). We can explain this gender gap by different argument. The first is the feminists' arguments: they argue that gender inequalities in the labor market constitute discrimination driven specifically by the subordinate position of women in society, a position which is
0.812

I.767**

$2.713 * * *$

1.196

(0.203)

$(0.220) \quad(0.204)$

I. $421 *$

$(0.297)$

I.5I 2**

I. $427^{*}$

(0.27I)

(0.226)

(0.283)

1.056

(0.22I)

$(0.227)$

(0.225)

2.37I***

2.384***

(0.390)

2.473***

$(0.38 \mathrm{I})$

$(0.38 \mathrm{I})$

0.710 **

$0.68 I^{* *}$

(0.121)

(0.122)

(0.125)

(0.1 I7)

\subsection{6}

1.009

1.010

0.974

$(0.182)$

$(0.179)$

$(0.179)$

$(0.173)$

0.772

0.746

0.788

0.745

(0.196)

$(0.209)$

(0.197)

I.688**

I.704**

I.729**

I.605*

(0.459)

$(0.426)$

0.753

(0.45I)

0.824

0.829

$(0.319)$

(0.320)

(0.35I)

I. $074 * * *$

$(0.355)$

I.08I***

$(0.0214)$

$\mathrm{I} .13 \mathrm{I}^{*} * *$
$(0.0217)$

(0.0272)

$(0.0242)$

86,513

86,513

86,513

86,513

0.0578

0.0592 
Interaction between human capital and socioeconomic background

In the previous explanatory analyses, we do not take into account interactions between variables, especially between variables measuring socioeconomic background and human capital. Not considering these interactions is tantamount to making the implicit assumption that the efficiency of education stays the same regardless of social background and vice-versa. In this in-depth analysis, we relax this assumption and see if returns to education are heterogeneous, i.e. whether they depend on the categories of variables that measure social origin. To do this, we built interaction effects models, corresponding to the cross product of education level categories with socioeconomic background variable (father's employment status and household wealth) categories. Before interpreting the results of the estimation, it is important to first present the cross tabulation of education by father's employment status and family of origin's wealth status.

Table 4. Cross tabulation of young people's education level by family background on leaving the education system

\begin{tabular}{lccccc} 
& \multicolumn{4}{c}{ Wealth status of household of origin } & \multicolumn{3}{c}{ Father's employment status } \\
& poor & non-poor & non-wage & wage & Total \\
\hline Primary & 42.0 & 20.7 & 38.9 & 23.5 & 33.5 \\
Lower secondary & 44.3 & 44.1 & 43.6 & 45.4 & 44.2 \\
Upper secondary and higher & 13.6 & 35.2 & 17.5 & 31.1 & 22.3 \\
\hline education & 100 & 100 & 100 & 100 & 100 \\
\hline Total & 557 & 372 & 601 & 328 & 929 \\
Numbers & & & & & \\
\hline
\end{tabular}

Table 4 shows that twice the number of young people from non-poor households attended upper secondary or higher education as those from poor households. The inverse is observed for primary school in that half the number of young people from non-poor as opposed poor households left the education system at primary level. As regards the father's employment status, we also observe that young people with wage-earner fathers performed better in school than those whose fathers were not wage earners (self-employed or unemployed). The gap between the two groups is almost the same as for household wealth. Even though the statistics here are descriptive, the inequalities found are well established in the literature (see, for example, Pasquier-Doumer, 2012; Kuepie and Missangumukini, 2012). However, it is worth noting that the proportion of children from disadvantaged families with upper secondary and higher education is far from negligible. This means that we can identify the interaction effects between family background and education level.

These estimations of interaction effects produce the following result: given a similar education level, young people from privileged social classes (in terms of the father's employment status or family wealth) enter the wage job sector more quickly than young people from poor socioeconomic background.

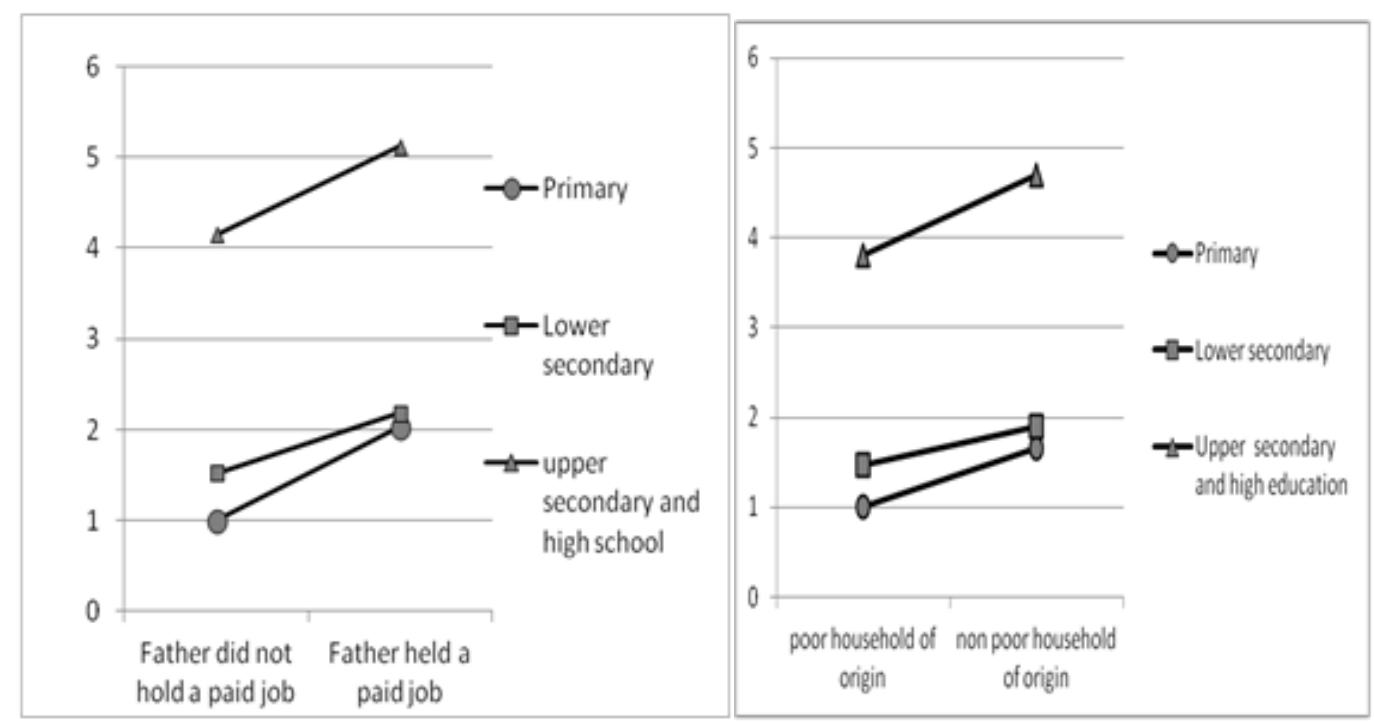

Figure 7. Interaction between education level and social origin (odds ratios from a Cox model). 
In the figure 7, the horizontal axis represents family background (father's employment status, and living conditions of family of origin) and the $y$-axis the impact of education level on access to a wage job. If young people with a given level of education had the same chances of finding a wage job irrespective of their family background, the corresponding line that we could call an iso-education line would be parallel to the $x$-axis. Yet all the lines have a positive slope, indicating the existence of a kind of "leverage" effect due to family background. This premium exists at all levels of education and for both socioeconomic background indicators. It is, in a manner of speaking, the "ratchet effect" highlighted by Thélot (1982) in the French case.

\section{Conclusion}

The purpose of this study was to measure the impact of socioeconomic background and human capital on young people's labor market integration in Bafia, a medium town in Cameroon. A review of the literature suggests that in addition to human capital, other factors not directly related to individual productivity play an important role in labor market integration. The empirical work is based on a firsthand biographical database from a Cameroonian city.

It comes from the analyses that Socioeconomic background, especially when measured by the father's employment status, seems to be an effective tool for entering the small, but well-paid wage job sector in Bafia. Indeed, young people from privileged background can draw on their families' social and economic resources to gain faster entry to the lucrative wage sector. However, it is important to note that although social capital secures advantages for some, it is simultaneously a factor for the exclusion of those who do not have it. Therefore, the "premium" enjoyed by those born into the right family contributes to labor market imperfections because it raises the potential gains for some players (those from privileged classes) when this increase is not justified by an increase in productivity. This situation can generate a feeling of unfairness among young people from poor families who, despite a high level of education, find it harder to secure a job in the wage sector just because they were not born into the right family. The sub-optimality of this labor market functioning mode (from the point of view that the collective product could be raised by recruiting young people on the basis of their skills) may explain, in part, the low productivity of the Cameroonian economy. Under optimal labor market functioning, all young people, regardless of their family background or networks, would have access to information on all available job vacancies and employers would select their employees based purely on their skills and education and not on their family background. We also observe that education is effective in integrating wage sector when the young person has completed upper secondary or higher education. Beyond this level, education seems not to be effective, once controlled for family background. This situation reflects a mismatch between education and the labor market. Young people with lower secondary education do not find corresponding jobs in the labor market, except when they followed technical education or when they are from privileged families.

\section{References}

Njoya A., Djomo S., Guillemin S., Mba M., Merceron S. et Torelli C. (2008), Dynamiques du marché de l'emploi à Yaoundé entre 1993 et 2005 : des déséquilibres persistants, STASTECO N ${ }^{\circ} 102$.

APEC (2006). La mobilité professionnelle des cadres. Les études de l'emploi cadre, APEC; 48 pages.

Arestoff F. (200I). Taux de rendement de l'éducation sur le marché du travail d'un pays en développement. Une analyse microéconométrique, Revue Economique, vol. 52, n`3, mai, pp. 705-I5.

Arriagada A-M and Ziderman A. (1992) "Vocational Secondary Schooling, Occupational Choice, and Earnings in Brazil”, WORKING PAPERS Policy Research, Educationa and Employment Population Human Resources Department, The World Bank, Novembe 1992, WPS 1037,

Asselin, L-M., (2002). Pauvreté multidimensionnelle. Institut de Mathématique Gauss, Québec, Canada.

Barlet M.(20/3) Urban Labor Market Segmentation in West Africa. In De Vreyer, Philippe, and François Roubaud, (Editors). Urban Labor Markets in SubSaharan Africa . Africa Development Forum series. Washington, DC: World Bank. doi:I0.1596/978-0-82 |3-978I-7. License: Creative Commons Attribution CC BY 3.0, PI95220

Becker, G.S.(1993). Human Capital. A theoretical and Empirical analysis, with special Reference to Education, 3rd edition, the Chicago Press, 4I 2p

Bennell, P. and Sergerstrom, J. (1998) "Vocational education and training in developing countries: Has the World Bank got it right?", International Journal of Educational Development 18 (4) (July): 27I-87.

Bocquier P. (1996). L'analyse des enquêtes biographiques à l'aide du logiciel STATA, document et manuels du CEPED, 220p.

Bourdieu P. (1980), Le capital social, Actes de la recherche en sciences sociales $n^{\circ} 31$, p. 2 
Bourdieu P. (1984). Espace social et genèse des classes, Actes de la recherche en sciences sociales, $n^{\circ} 52-53$.

Brilleau A., Roubaud F. Torelli C. (2004). L'emploi, le chômage et les conditions d'activité. Enquête I-23 Phase I, STATECO $\mathrm{n}^{\circ}$ 99, p4 I-62

Burt, Ronald S. (1995). Structural holes: the social structure of competition. Harvard University Press, $3 \mid 2 p$

Cogneau D. and S. Mesplé-Somps, (2008). Inequality of Opportunity for Income in Five Countries of Africa, in Bishop J. and B. Zheng (eds): Inequality and Opportunity: Papers from the Second Ecineq Society Meeting, Research on Economic Inequality, vol. 16, Emerald.

Coleman, J. (1988). Social Capital in the Creation of Human Capital. American Journal of Sociology Supplement 94: pp95-I 20.

Collier, Paul. 1994. Gender Aspects of Labour Allocation During Structural Adjustment - A Theoretical Framework and the African experience. in Susan Horton, Ravi Kanbar and Dipak Mazumdar (eds.) Labor Markets in an Era of Adjustment, Vol. I. World Bank. Washington.

Courgeau D., Lelièvre E. (1989). Analyse démographique des biographies, éditions de I'INED Paris, $270 \mathrm{p}$

Cox, D. R. and D. Oakes. 1984. Analysis of Survival Data, Chapman and Hall, London. 20Ip

De la Fuente, A., Ciccone, A. (2002). Human capital and growth in a global and knowledge based economy. Report for the European Commission, DG for Employment and Social Affairs

Doumbia A. G et Kuepie M. (2008). Niveau et déterminants de l'insertion des femmes sur le marché du travail au Mali, 2008. STATECO $\mathrm{n}^{\circ}$ I03, pp6I-75

Durkheim E (1893) De la division du travail social, Paris, PUF

Filmer D. and Pritchett L. (200I). Estimating Wealth Effects without Expenditure Data-or Tears: An Application to Educational Enrollments in States of India Deon ; Demography, Vol. 38, No. I, pp. II5-132

Fraihat H. S. (2003). Insertion professionnelle des diplômés de l'enseignement supérieur : disparités entre filles et garçons communication au colloque "Marché du travail et genre dans les pays du Maghreb", Rabat, II et I 2 avril 2003

Gertler P., Heckman J., Pinto R., Zanolini A., Vermeersch C., Walker S., Chang S.M., \& Grantham-McGregor S. (20|3). "Labor Market Returns to Early Childhood Stimulation: a 20-year Followup to an Experimental Intervention in Jamaica,"NBER Working Papers 19185, National Bureau of Economic Research, Inc
Heckman, James J. 2012. "Creating and Measuring Capabilities", Keynote Lecture. The Third International Conference on Poverty Alleviation and Child Development. China Development Research Fondation. Beijing, October 2012.

Kouame A. Kuepie M. and Tameko D. (200I). Crise, Réformes des politiques économiques et emploi à Yaoundé, Les dossiers du CEPED n 64, Paris

Kuepie M. and Misangumukini N. (20/2). Environnements économique et éducatif des ménages et échec scolaire des enfants au Mali ", L'actualité Economique, Volume 88, No 4, décembre 2012

Kuepie M., Nordman C.J. (20II). Education and Labour Markets in Brazzaville and Pointe-Noire (Congo-Brazzaville)", Background paper for the Employment and Growth Study for the Republic of Congo, The World Bank; DIAL Research Paper $\mathrm{DT} / 20 \mathrm{II} / \mathrm{I}$ I

Kuépié, M., Nordman, C.J. and Roubaud, F. (2009). Education and Earnings in Urban West Africa. Journal of Comparative Economics 37 (3), p. 49I$5 \mid 5$.

Locoh T., Tichit C. (1996). Introduction. in : T. Locoh, A. Labourie-Racapé and C. Tichit (ed). Genre et développement : des pistes à suivre, Documents et manuels du CEPED, $n^{\circ}$ 5, Paris, $p$. I-8.

Mambou P.F., (2008). Stratégies d'insertion des jeunes de la ville de Yaoundé, mémoire à I' www.memoireonlle.com/01//0/3259

Marx K. (1867), Le Capital, PUF

Middleton, J.A., Ziderman, A. and Adams, A. V. (1993) Skills for Productivity: Vocational Education and Training in Developing Countries. Oxford University press, New York.

Moenjak, T. and Worswick, C. (2003) "Vocational education in Thailand: a study of choice and returns", Economics of Education Review, 22, pp.99-I07.

Montgomery, J. D. (199I). Social networks and persistent inequality in the labor market. Center for Urban Affairs and Policy Research.

Munshi K. 2014. Community Networks and the Process of Development. Journal of Economic Perspectives, Volume 28, Number 4, P.49-76

Nordman C.J, Rakotomanana F. and Robilliard A.S. (2009). Gender Disparities in the Malagasy Labour Market. Document De Travail DT/2009-08

Pasquier-Doumer L. (20I2). Inequality of Opportunity in the Urban Labour Market in West Africa. Revue d'Economie du Développement, vol.26(2), p.44-66

Peugny C. (2007). Éducation et mobilité sociale : la situation paradoxale des générations nées dans les 
années 1960. Économie et Statistique $n^{\circ} 410$, P2345

Peugny C. (20I3). Le destin au berceau. Inégalités et reproduction sociale, Seuil I28p.

Poullaouec T. (2003). Les familles ouvrières face aux destins sociaux de leurs enfants à travers les générations. in "Les approches générationnelles : enjeux, avancées, débats". Journées d'études des 13 et 14 novembre 2003 organisées par le Laboratoire Printemps UMR 8085, CNRS et Université de Versailles Saint-Quentin-en-Yvelines Laboratoire Printemps, $18 \mathrm{p}$

Psacharopoulos G. \& Patrinos H.A. (2004). "Returns to investment in education: a further update," Education Economics, Taylor \& Francis Journals, vol. I2(2), pages II I-I34.

Putman R. (2000). Bowling Alone: The Collapse and Revival of American Community. Simon and Shuster, 544p
Reich, M. Gordon, D.M. and Edwards, R.C., "Dual Labor Markets: A Theory of Labor Market Segmentation" (1973). American Economic Review 63:2 (May 1973), pp. 359-365.

Silberman R., Foumier I. (1999), "Les enfants d'immigrés sur le marché du travail : les mécanismes d'une discrimination sélective ", Formation/Emploi n 65 , p.31-55.

Soukup A. (2007). "Human capital, screening theory and education in agriculture", Agric. Econ. Czech, 53, 2007 (I0): 475-478

Spence M. (1998), Market Signalling. Cambridge, Massachusetts.

Thélot, (1982). Tel père tel fils? Position sociale et origine familiale, Bordas Paris, 1982, 4I 0p

\section{APPENDIX:}

Table IA. Distribution (in \%) of variables used in the multiple correspondence factorial analysis

\begin{tabular}{|c|c|c|c|}
\hline \multirow{2}{*}{\multicolumn{2}{|c|}{ Housing characteristics }} & \multicolumn{2}{|c|}{ Percentage of young people living in a household with } \\
\hline & & Mobile/landline phone & 51.5 \\
\hline Detached house & 49.5 & Computer & 6.2 \\
\hline Block of flats & 31.9 & Radio & 81.7 \\
\hline Modern villa & 5.7 & TV & 65.0 \\
\hline Compound/Saré & 11.9 & $\mathrm{Hi}$ Fi/stereo player & 34.5 \\
\hline Unknown & 1.0 & Satellite dish & 7.7 \\
\hline Main wall material & & Car & 14.9 \\
\hline Cut stone & 50.7 & Motorbike & 23.3 \\
\hline Simple brick & 21.9 & Rickshaw & 31.5 \\
\hline Clay/adobe & 26.8 & Bicycle & 8.0 \\
\hline Other (specify) & 0.6 & Vegetable mill/grinder & 17.5 \\
\hline Main floor material & & Refrigerator & 31.4 \\
\hline Marble/tiles/wood & 5.0 & Generator & 3.5 \\
\hline Cement & 73.6 & Stove/cooker & 31.0 \\
\hline Earth & 21.3 & Air conditioning & 1.5 \\
\hline Unknown & 0.2 & Agricultural land for crops or livestock & 62.9 \\
\hline Main source of water supply & & Poultry/livestock & 24.5 \\
\hline Borehole/CAMWATER water in dwelling & 25.2 & & \\
\hline Borehole/ CAMWATER water outside dwelling & 29.7 & & \\
\hline Wells/improved wells & 35.9 & & \\
\hline Open source water supply/well & 8.7 & & \\
\hline Other (specify) & 0.5 & & \\
\hline \multicolumn{4}{|l|}{ Main light source } \\
\hline Electricity & 83.5 & & \\
\hline Lamp & 16.1 & & \\
\hline Other & 0.1 & & \\
\hline
\end{tabular}


Unknown

Main source of cooking power supply

Gas/electricity

Coal/sawdust/shavings

Wood

Unknown

Type of lavatory

WC with flush

16.3

Improved latrine

58.3

Unimproved latrine

25.3

Unknown

0.1 